\title{
Systematic Review of Research in Second Language Acquisition: A Snapshot of the Past Ten Years (2009 - September 2019)
}

\author{
Amirreza Karami \\ University of Arkansas, akarami@uark.edu
}

Abstract

The purpose of this systematic review is to provide second language acquisition (SLA) researchers with an overview of research trends in this field in the last ten years (2009-2019). In doing so, three international peer-reviewed journals, Studies in Second Language Acquisition, Language Teaching Research, and The Modern Language Journal, were selected. 150 articles were systematically selected and analyzed. The analysis of data resulted in identifying six descriptive themes. Results showed that some areas of second language acquisition still need further exploration while some areas are of great interest for researchers. Some suggestions for future research as well as implications of the study were discussed in detail.

Keywords: systematic review; second language acquisition; research interests; second language teaching and learning 
SYSTEMATIC REVIEW OF RESEARCH IN SLA

\section{Introduction}

Second language acquisition is the acquisition of a new language beyond one's first language. Although researchers and scholars distinguish between learning and acquisition, these two words are used interchangeably in SLA research. Not only are learning and acquisition used interchangeably. Second language and foreign language are used in a similar fashion as well (Chen, 2018). Second language acquisition (SLA) has experienced an enormous expansion in terms of research and methodology since its inception (Pica, 2005). This increase of research is one of the most influential reasons for researchers to branch out into areas that previously were unexplored. As the number of studies in SLA increase, the number of topics, language teaching methodologies and theories increases, too. Pica (2005, p. 1) mentioned this wide range of enhancement in SLA and research and stated that "the field has become increasingly bidirectional and multi-faceted in its applications." This wide spectrum needs to be summarized in an organized and systematic way to let researchers keep up with the pace and find out what has already been done in the past and what needs to be done in the future.

Larsen-Freeman (2018b) explained the history of the modern-day study of second language acquisition (SLA) briefly. "The modern-day study of SLA" established by the help of Corder (1967) and Selinker (1972) moved to recent ideas of teaching second language such as form-focused instruction (Larsen-Freeman, 2018b, p. 56-57). The author is also concerned with the complexity of the acquisition of a second language in modern days. This complexity is due to various effective factors that not only seem to act independently, are dependent on each other as well. "This means that while some SLA researchers will continue to identify new variables, others will not simply focus on one component of a complex developing system but rather will look at the changing relationships among many of them" (Larsen-Freeman, 2018b, p. 59).

In doing so, this systematic review focuses on research in SLA by focusing on topics and findings of studies published in three international, peer-reviewed empirical journals, Language Teaching Research, 
SYSTEMATIC REVIEW OF RESEARCH IN SLA

Studies in Second Language Acquisition, and The Modern Language Journal, during the past ten years (2009September 2019). The purpose of this systematic review is to provide researchers with an overview of various aspects of SLA research that have been considered by researchers and scholars as hot topics or hot areas of research at least in the past decade. Although "various strategies, techniques, methods, tools, and technologies" have been applied by teachers to ease convoluted language learning process, there is still a need for further exploration of some aspects (Karami, 2019, p. 60).

This review answers two research questions by focusing on topics and focus of articles. The research questions are as follows:

1) What basic topics seem to be of interest to researchers in your discipline in the past decade?

2) What trends in the topics of interest during that time?

\section{Methodology}

To investigate topics of interest and research areas in the field of second language acquisition (SLA), a systematic review was conducted using three international, peer-reviewed journals. Language Teaching Research, Studies in Second Language Acquisition, and The Modern Language Journal were selected due to their strong focus on SLA, their ranking, their peer-review policy, their impact factor, and their popularity among SLA researchers and scholars.

Total number of 1306 articles including, research studies, literature reviews, research reports, and so on were published in these journals during the past ten years from 2009 up to September 15, 2019. Editorial notes or some other types of articles published by editors or guest editors such as introduction to this issue by editors have been excluded from this number. Figure 1 shows the number of articles published by each journal separately from 2009 to September 2019. 


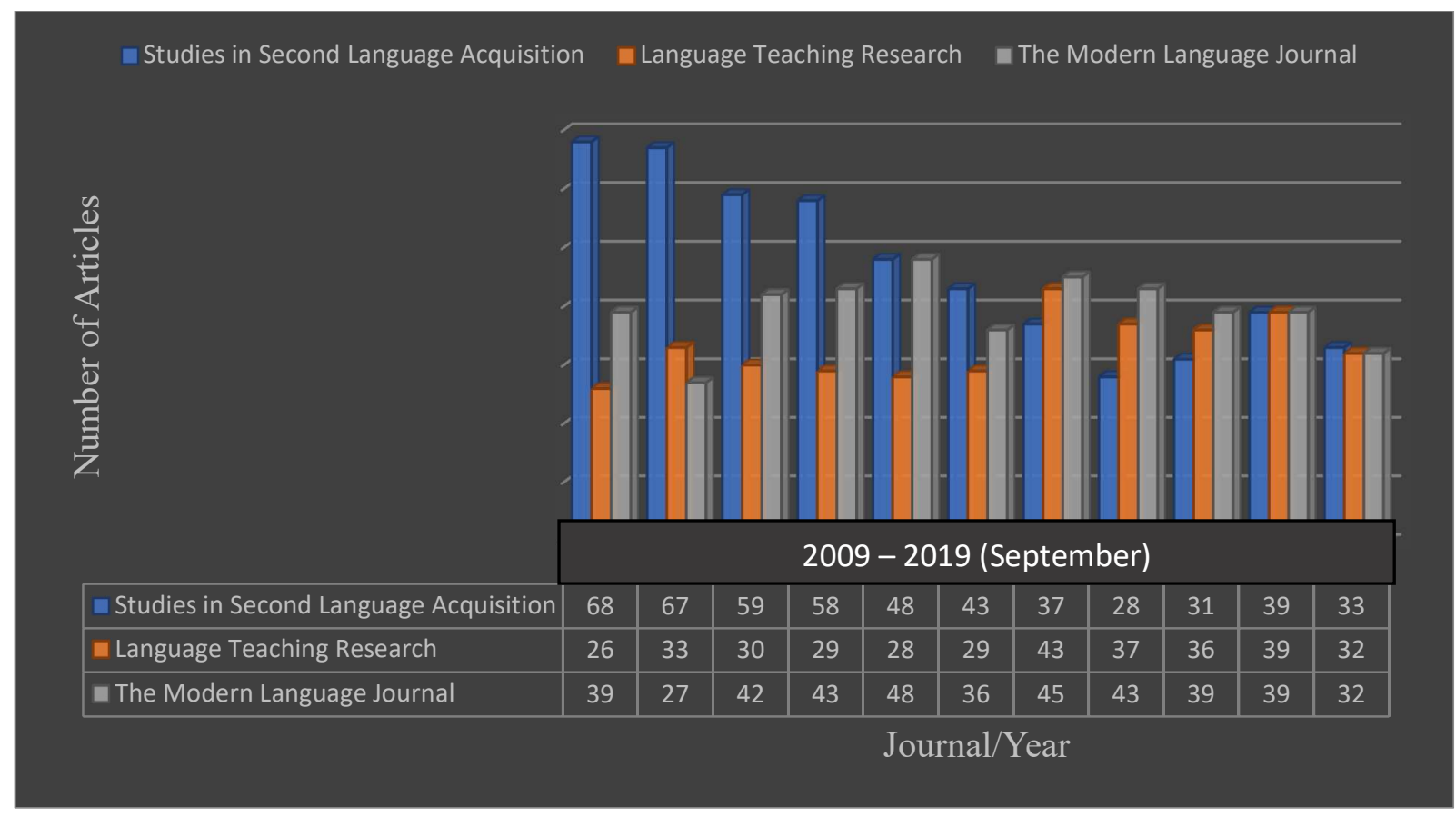

Figure 1. Number of Articles Published in Three International, Peer-Reviewed empirical Journals from 2009 - September 2019

Since the intended number of articles to be included in this systematic review was 150 in total and 50 from each journal, the articles were selected from each journal based on the following table:

Table 1. Article Search Criteria.

\begin{tabular}{|c|c|c|c|}
\hline Name of the Journal & $\begin{array}{c}\text { Total Number of } \\
\text { Articles Published } \\
\text { in Each Journal } \\
(2000-\text { September } \\
2019)\end{array}$ & Selection Criteria & $\begin{array}{c}\text { Total Number of } \\
\text { Articles Selected } \\
\text { from Each Journal }\end{array}$ \\
\hline $\begin{array}{c}\text { Studies in Second Language } \\
\text { Acquisition }\end{array}$ & 511 & $\begin{array}{c}\text { Every } 10^{\text {th }} \text { article } \\
511 / 50 \simeq 10\end{array}$ & 50 \\
\hline Language Teaching Research & 362 & $\begin{array}{c}\text { Every } 7^{\text {th }} \text { article } \\
362 / 50 \simeq 7\end{array}$ & 50 \\
\hline The Modern Language Journal & 433 & $\begin{array}{c}\text { Every } 9^{\text {th }} \text { article } \\
433 / 50 \simeq 9\end{array}$ & 50 \\
\hline
\end{tabular}

The first journal (Studies in Second Language Acquisition) has four issues for each year with six to eight articles in each issue. This journal publishes $A$ Word from the Editor in each issue as well as 
SYSTEMATIC REVIEW OF RESEARCH IN SLA

Research Reports, SLA Cover and Front Matter, and SLA Cover and Back Matter. The author of this systematic review focused on the main body of each issue and articles published under the name of Research Article.

The number of articles in each issue in the second journal (Language Teaching Research) was around eight with one number above or below. So, the first article from each issue was selected with disregarding Editorial Notes, Editorial Introduction, and Notes on Contributors. In other words, the first article in the main body of each issue were considered to be included in this systematic review.

The Modern Language Journal is published in fours issue with one supplemental issue each year. Each issue includes both research articles and review papers. Since the number of articles published in each issue is around seven to ten, the author decided to choose the first article from each issue. Figure 1 shows an overview of the systematic search process.

\begin{tabular}{|c|c|c|}
\hline Journals & $\begin{array}{c}\text { Exclusion Criteria } \\
\text { Studies in Second } \\
\text { Language } \\
\text { Acquisition } \\
\text { Language } \\
\text { Research reports } \\
\text { SLA cover and front } \\
\text { Teaching Research } \\
\text { The Moder } \\
\text { SLA cover and back } \\
\text { Language Journal }\end{array}$
\end{tabular}

Figure 2. An overview of the systematic search process of articles in three international, peer-reviewed journals from 2009-2019

Following the selection criteria of articles from three international, peer-reviewed journals, a table (see Appendix I, II, and III) was constructed to capture the most important information of articles such as their focus, type, data collection method, and results.

Thematic analysis, which was defined by Braun and Clarke (2006, p. 6) as "a method for identifying, analysing, and reporting patterns (themes) within data," was used to analyze data. In doing 
SYSTEMATIC REVIEW OF RESEARCH IN SLA

so, a table was provided (see Appendix IV) by following recommended steps of Braun and Clarke (2006). Careful analysis of data led to six descriptive themes.

\section{Identified Themes}

1) Language Teaching Strategies and Pedagogical Recommendations for Teachers

It seems that teaching strategies and pedagogical practices are of the greatest concern for researchers in the field of second language acquisition. The total number of studies that have put language teaching strategies and pedagogical practices into consideration is 63 which is $42 \%$ of the total articles (150) that were selected to be included in this study. Language teaching strategies and pedagogical practices that include more than one-third of research studies are but not limited to strategies and practices such as peer-interaction, form-focused instruction, explicit and implicit instruction, assessment strategies, feedback, task repetition, input and output-based instruction, task-based language teaching, language teaching materials, student engagement, teacher's knowledge, grammar pedagogy, teachers' professional development, and so on.

2) Language Skills, Subskills, and Development

The second most important area of research for second language acquisition researchers is language skills and subskills. Listening, speaking, reading, and writing as main skills or macro skills of a language and vocabulary, grammar, pronunciation as subskills or micro skills of a language. The results of the thematic analysis showed that 45 articles out of 150 (30\%) fall in this category. Within that $30 \%, 18$ out of 46 articles (39.13\%) have focused on grammar and its integration with other areas such as reading, writing, phonology, and so on. Studies about vocabulary and its integration into other areas such as vocabulary development, vocabulary and reading, vocabulary acquisition and phonology, and so on stand second with 15 out of 46 (32.60\%) studies. 


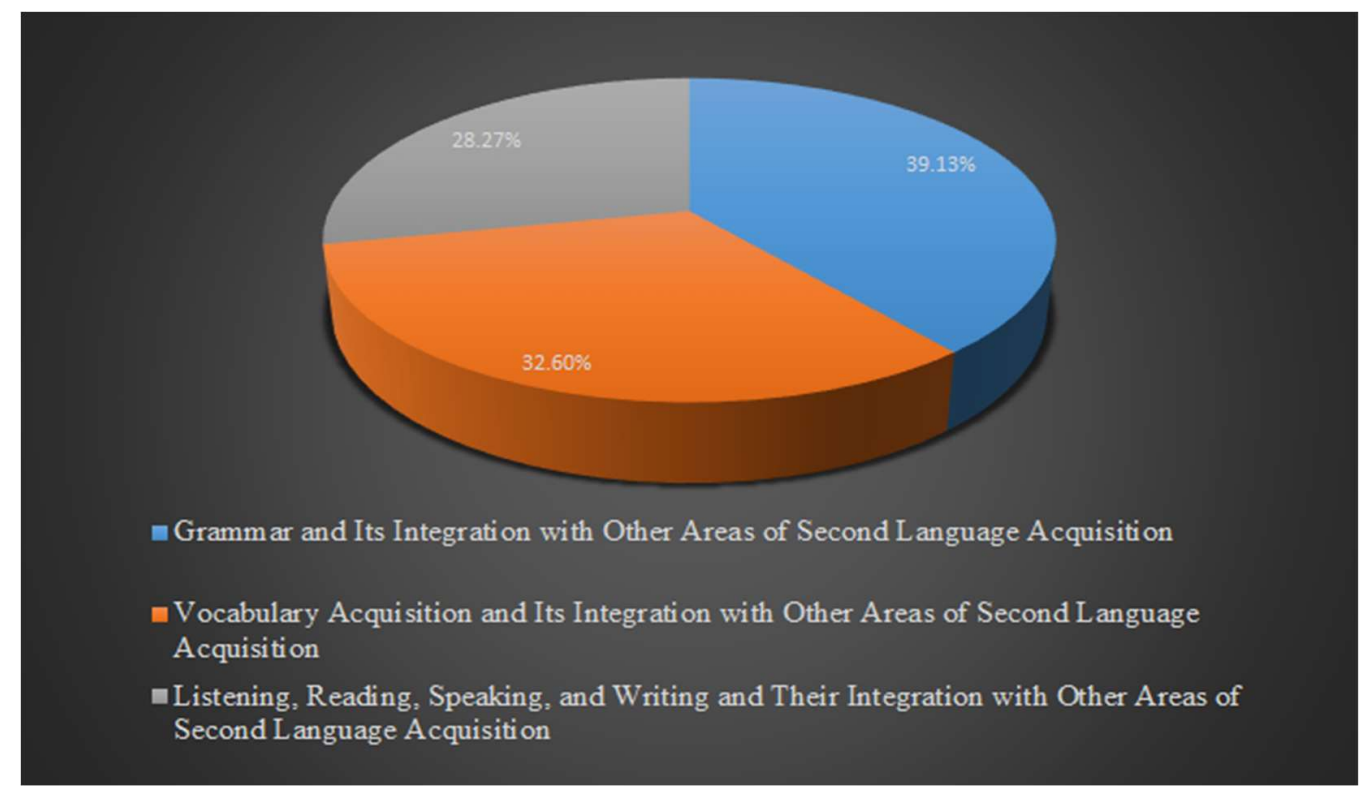

Figure 3. Research contributions to language skills, subskills, and language development within past ten years

3) Advanced Influential Factors in Second Language Acquisition

Factors such as the learner's motivation, attitudes, aptitudes, self-efficacy, language competence, awareness, learners' perception, individual differences, inner speech, learners' attention, and pragmatics are some examples of these influential factors. The thematic analysis shows that 18 out of 150 articles (12\%) can be considered as advanced influential factors in second language acquisition and ranked third most important research area in this systematic review.

4) Memory and Language Development

Working memory and its integration with other areas such as cognition and metacognition are the most considerable area that researchers focus on in this category. The thematic analysis shows that 13 out of 150 articles (almost $8 \%$ ) in this field are related to memory and language development.

5) Segmental and Supersegmental Features

Segmental and supersegmental features of a language such as phonology, intonation, pause, and so on with their integration into other areas of a language cover almost $4 \%$ ( 7 articles) of the total number (150). 
6) Social Aspects in Second Language Acquisition

Social aspects such as cultural aspects of second language acquisition, its related theories such as sociocognitive theory, and its integration with other areas of language such as listening comprehension cover $4 \%$ (6 articles) of the total number (150).

\section{Conclusions}

To answer the first research question which is about the basic topics of interest to researchers in the field of Second Language Acquisition (SLA), figure 4 was provided. This figure shows topics of interest to SLA researchers based on the identified themes. Each theme has been presented with its relevant percentage to clearly represent the importance of the topic.

The results of this systematic review show that teacher and teaching strategies are of the greatest importance for researchers and scholars in the field of second language acquisition. This figure represents the importance of language teaching strategies and pedagogical recommendations for SLA researchers within the past ten years and shows that $42 \%$ of studies focus on teachers as the key role in second language classrooms. The second most important area of research focuses on skills and subskills of a language such as listening, speaking, grammar, and so on. Factors such as motivation, attitude, selfefficacy, and some other factors that fall in this category ranked third. Research around memory placed fourth, segmental and supersegmental features ranked fifth, and social aspects such as culture have considered to be the least important areas of research for researchers. 


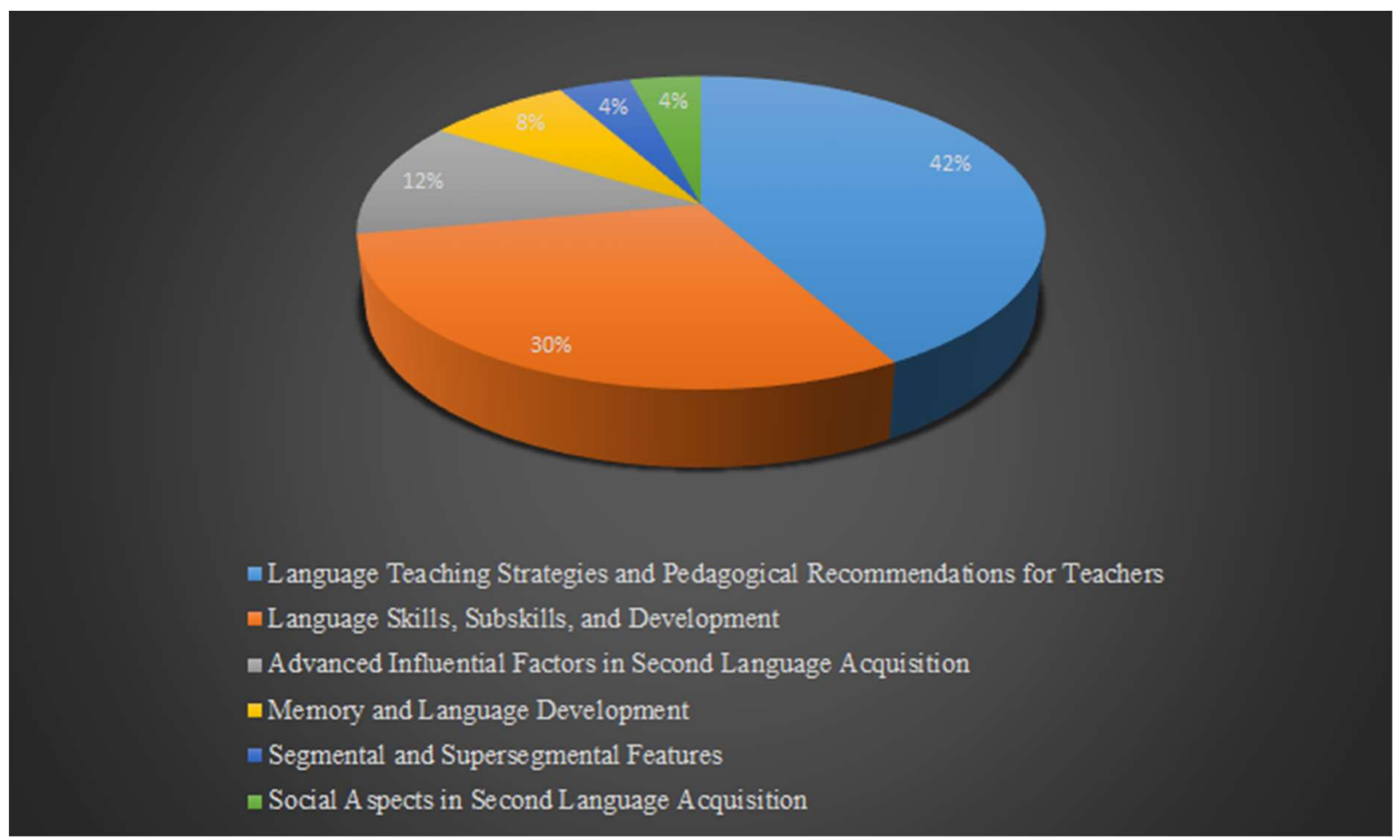

Figure 4. The importance of research areas for second language researchers

Figure 5 displays the number of theme-related studies published each year. The results show that the number of studies related to language skills, subskills, and development increased dramatically in 2018 although these areas have always been in the forefront of researchers' attention. It is also obvious from this figure that the number of articles related to language teaching strategies and pedagogical recommendations for teachers have stayed the same within the last three years. The number of articles about memory and language development decreases while it seems that social aspects and advanced influential factors are getting more attention from researchers. 


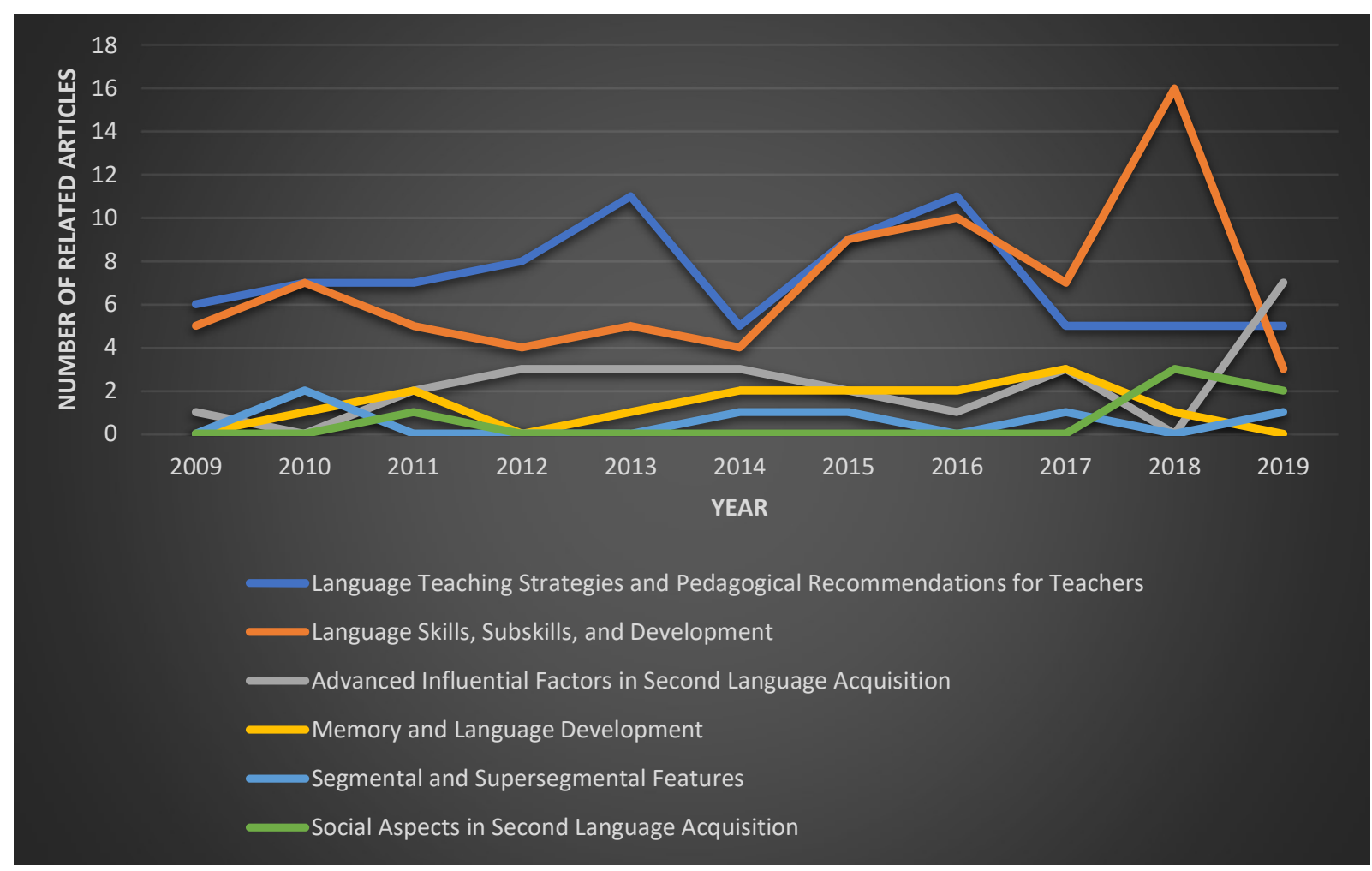

Figure 5. Research interests within the last 10 years

\section{Implications of the study}

This literature review can help second language researchers and scholars to get an overview of what topics seem to be important for second language researchers, what has been done, and what areas need further investigation. The results of this systematic review clarify the importance of areas of second language acquisition that researchers are most concerned with. It seems that researchers tend to focus more on the combination of different aspects rather than focusing on just one specific area. Researchers emphasized on this and argued that strategies can not lead to the development of language unless they are integrated with each other (Elleman \& Oslund, 2019). This also highlights the idea that different parts of a language cannot be separated from each other and cannot be taught in isolation that is in line with the argument of Larsen-Freeman (2018b, p. 63) about future directions in second language acquisition research in which language development needs to be understood "from a system perspective." 
The results of this systematic review of research in the field of second language acquisition (SLA) also show that the roles of social aspects, memory, and segmental and supersegmental features in language development remain unexplored and need further exploration. Larsen-Freeman (2018b, p. 67) mentioned these areas as future directions in SLA research and stated that not only will SLA researchers "continue to inquire into the cognitive, the social, and the sociocognitive dimensions of the SLA process," but also will "look into the ever-changing relationships among the components within the language learner's developing system." For example, pragmatic which is crucial for successful language learning needs to be taught in context. Providing appropriate context for second language learners can help them to bridge between the meaning of words and sentences and "what the speaker intended to communicate" (Papafragou, 2018, p. 167). So, focusing on less explored areas such as social and cultural aspects can lead to more successful language learning.

This review can also help language teachers and educators to find out more about their key roles in second language classrooms. Researchers still believe that teachers play the most important role in the process of language teaching and learning. So, researchers investigate ways to improve teachers' roles and boost their impact on the process of language learning. Teachers and the teaching strategies that they implement in their classrooms can be successful if they are based on analytical and theoretical perspectives. Teachers should know that they have access to plenty of research studies that are scientific, and theory based. So, they should "remain well-informed and tenacious as a way of keeping fully up to date with recent changes in pedagogic principles to disseminate knowledge" (Karami, 2016, p. 242). Second language teachers and educators can implement these strategies, techniques, and methods to smooth out difficulties that language learners might suffer in the process of second language acquisition. 


\section{References}

Baills, F., Suárez-González, N., González-Fuente, S., \& Prieto, P. (2019). Observing and producing pitch gestures facilitates the learning of mandarin chinese tones and words. Studies in Second Language Acquisition, 41(1), 33-58.

Braun, V., \& Clarke, V. (2006). Using thematic analysis in psychology. Qualitative Research in Psychology, $3(2), 77-101$.

Chen, M. L. (2018). A data-driven critical review of second language acquisition in the past 30 years. Publications, 6(3), 1-29.

Corder, S. P. (1967). The significance of learner's errors. International Review of Applied Linguistics, 5, 161170 .

Elleman, A. M., \& Oslund, E. L. (2019). Reading comprehension research: Implications for practice and policy. Policy Insights from the Behavioral and Brain Sciences, 6(1), 3-11.

Hirakawa, M., Shibuya, M., \& Endo, M. (2019). Explicit instruction, input flood or study abroad: Which helps japanese learners of english acquire adjective ordering? Language Teaching Research, 23(2), 158-178.

Jung, Y., Kim, Y., \& Lee, H. (2019). Learner perception of multimodal synchronous computer-mediated communication in foreign language classrooms. Language Teaching Research, 23(3), 287-309.

Kang, E. Y., Sok, S., \& Han, Z. (2019). Thirty-five years of ISLA on form-focused instruction: A metaanalysis. Language Teaching Research, 23(4), 428-453.

Karami, A. (2016). What makes a good teacher? Needs and necessities. A survey of recent literature on teacher's subject matter knowledge, pedagogical knowledge, and pedagogical content knowledge. Journal of Studies in Education, 6(2), 241-250.

Karami, A. (2019). Implementing audio-visual materials (videos), as an incidental vocabulary learning strategy, in second/foreign language learners' vocabulary development: A current review of the most recent research. i-manager's Journal on English Language Teaching, 9(2), 60-70.

Larsen-Freeman, D. (2018b). Looking ahead: Future directions in, and future research into, second language acquisition. Foreign Language Annals, 51, 55-72.

Lin, M. H., \& Lee, J. Y. (2019). Pedagogical suitability of data-driven learning in EFL grammar classes: A case study of Taiwanese students. Language Teaching Research, 23(5), 541-561.

López-Serrano, S., Roca de Larios, J., \& Manchón, R. M. (2019). Language reflection fostered by individual L2 writing tasks. Studies in Second Language Acquisition, 41, 503-527.

Nakata, T., \& Suzuki, Y. (2019). Effects of massing and spacing on the learning of semantically related and unrelated words. Studies in Second Language Acquisition, 41(2), 287-311.

Papafragou, A. (2018). Pragmatic development. Language Learning and Development, 14(3), 167-169.

Pica, T. (2005). Second language acquisition research and applied linguistics. In E. Hinkel (Ed.), Handbook of research in second language teaching and learning (pp. 263-280). Mahwah, NJ: Lawrence Erlbaum Associates, Publishers.

Reid, K., Trofimovich, P., \& O'Brien, M. (2019). Social attitudes and speech ratings: effects of positive and negative bias on multiage listeners' judgments of second language speech. Studies in Second Language Acquisition, 41(2), 419-442. 
Selinker, L. (1972). Interlanguage. International Review of Applied Linguistics, 10, 209-231.

Subtirelu, N. C., Borowczyk, M., Hernandez, R. T., \& Venezia, F. (2019). Recognizing whose bilingualism? A critical policy analysis of the seal of biliteracy. Modern Language Journal, 103(2), 371-390.

Suzuki, Y., Nakata, T., \& DeKeyser, R. M. (2019a). Optimizing second language practice in the classroom: Perspectives from cognitive psychology. Modern Language Journal, 103, 551-561. 
Appendix I

A sample of data from Studies in the Second Language Acquisition journal

\begin{tabular}{|c|c|c|c|c|c|}
\hline \multicolumn{6}{|c|}{ Studies in Second Language Acquisition } \\
\hline Number & Author(s) & Topic & Focus of Article & $\begin{array}{l}\text { Data } \\
\text { Collection } \\
\text { Method } \\
\end{array}$ & Results \\
\hline 1 & $\begin{array}{l}\text { Lopez- } \\
\text { Serrano, de } \\
\text { Larios, \& } \\
\text { Manchon } \\
\text { (2019) }\end{array}$ & $\begin{array}{l}\text { Language reflection } \\
\text { fostered by individual } \\
12 \text { writing tasks: } \\
\text { Developing a } \\
\text { theoretically motivated } \\
\text { and empirically based } \\
\text { coding system }\end{array}$ & $\begin{array}{l}\text { The connection } \\
\text { between } \mathrm{L} 2 \text { writing } \\
\text { process, its } \\
\text { reflection on } \\
\text { language and } \\
\text { language } \\
\text { development }\end{array}$ & $\begin{array}{l}\text { Argumentative } \\
\text { essay writing of } \\
21 \text { EFL learners } \\
\text { were analyzed }\end{array}$ & $\begin{array}{l}\text { Participants were concerned about lexical } \\
\text { knowledge. They also paid more attention } \\
\text { to clauses and larger structures in writing. } \\
\text { The authors suggested theoretical } \\
\text { frameworks for future research as well. }\end{array}$ \\
\hline 2 & $\begin{array}{l}\text { Nakata and } \\
\text { Suzuki } \\
(2019)\end{array}$ & $\begin{array}{l}\text { Effects of massing and } \\
\text { spacing on the learning } \\
\text { of semantically related } \\
\text { and unrelated words }\end{array}$ & \begin{tabular}{l|} 
The relationship \\
between learning \\
semantically related \\
words \\
simultaneously and \\
vocabulary \\
acquisition \\
\end{tabular} & $\begin{array}{l}\text { Vocabulary } \\
\text { intervention } \\
\text { (pre-test, post- } \\
\text { test design) }\end{array}$ & $\begin{array}{l}\text { Words that were semantically related "led to } \\
\text { more interference errors than unrelated } \\
\text { items" (p. 287) }\end{array}$ \\
\hline 3 & $\begin{array}{c}\text { Reid, } \\
\text { Trofimovich } \\
\text { \& O'Brien } \\
\text { (2019) }\end{array}$ & $\begin{array}{l}\text { Social attitudes and } \\
\text { speech ratings: Effects } \\
\text { of positive and negative } \\
\text { bias on multiage } \\
\text { listeners' judgments of } \\
\text { second language } \\
\text { speech } \\
\end{array}$ & $\begin{array}{l}\text { The relationship } \\
\text { between social bias } \\
\text { manipulation on } \\
\text { listening } \\
\text { comprehension of } \\
\text { naive listeners }\end{array}$ & Survey & $\begin{array}{l}\text { "Findings cast doubt on the relative stability } \\
\text { of } L 2 \text { speech ratings and point to the } \\
\text { importance of social context and } \\
\text { generational differences in untrained rater } \\
\text { assessments of } L 2 \text { speaking performance" } \\
\text { (p. 419). }\end{array}$ \\
\hline 4 & $\begin{array}{l}\text { Baills, } \\
\text { Suarez- } \\
\text { Gonzalez, } \\
\text { Gonzalez- } \\
\text { Fuente, \& } \\
\text { Prieto } \\
(2019)\end{array}$ & $\begin{array}{l}\text { Observing and } \\
\text { producing pitch } \\
\text { gestures facilitates the } \\
\text { learning of mandarin } \\
\text { chinese tones and } \\
\text { words }\end{array}$ & $\begin{array}{l}\text { The effects of } \\
\text { having knowledge } \\
\text { about metaphoric } \\
\text { gestures and its } \\
\text { effects on learning } \\
\text { L2 supersegmental } \\
\text { features }\end{array}$ & $\begin{array}{l}106 \text { participants } \\
\text { were taught } \\
\text { pitch gestures }\end{array}$ & $\begin{array}{l}\text { Gaining knowledge about the metaphoric } \\
\text { gestures is a beneficial strategy on the } \\
\text { acquisition of supersegmental features }\end{array}$ \\
\hline
\end{tabular}


Appendix II

A sample of data from Language Teaching Research journal

\begin{tabular}{|c|c|c|c|c|c|}
\hline \multicolumn{6}{|c|}{ Language Teaching Research } \\
\hline Number & Author(s) & Topic & Focus of Article & $\begin{array}{l}\text { Data Collection } \\
\text { Method }\end{array}$ & Results \\
\hline 1 & $\begin{array}{c}\text { Lin and Lee } \\
(2019)\end{array}$ & \begin{tabular}{|l|} 
Pedagogical \\
suitability of data- \\
driven learning in efl \\
grammar clasges: A \\
case study of \\
taiwanese students \\
\end{tabular} & Grammar & $\begin{array}{l}52 \mathrm{EFL} \text { learners were } \\
\text { divided into one control } \\
\text { group and two } \\
\text { experimental groups. } \\
\text { Covariance analysis } \\
\text { was used to analyze } \\
\text { data. }\end{array}$ & $\begin{array}{l}\text { The results of the study showed no } \\
\text { significant difference between control } \\
\text { group and two experimental groups. } \\
\text { "The overall results lend support to } \\
\text { the legitimacy of practicing DDL in } \\
\text { different educational areas" (P. 541). }\end{array}$ \\
\hline 2 & $\begin{array}{c}\text { Kang, Sok, } \\
\& \text { Han } \\
(2019)\end{array}$ & $\begin{array}{l}\text { Thirty-five years of } \\
\text { ISLA on form- } \\
\text { focused instruction: } \\
\text { A methodological } \\
\text { synthesis }\end{array}$ & $\begin{array}{l}\text { Form-focused } \\
\text { instruction }\end{array}$ & $\begin{array}{l}88 \text { quasi-experimental } \\
\text { studies were selected } \\
\text { from six journals. The } \\
\text { authors analyzed } \\
\text { articles based on five } \\
\text { variables including } \\
\text { context, research } \\
\text { design, participants, } \\
\text { intervention, and } \\
\text { outcome measures. }\end{array}$ & $\begin{array}{l}\text { The results showed that since } 2000 \text {, } \\
\text { the number of studies, pretest and } \\
\text { posttest design studies, and the } \\
\text { number of implicit instructions in } \\
\text { studies have increased although there } \\
\text { are still some weaknesses. }\end{array}$ \\
\hline 3 & $\begin{array}{l}\text { Jung, Kim, } \\
\text { Lee, Cathey, } \\
\text { Carver, \& } \\
\text { Skalicky } \\
(2019)\end{array}$ & \begin{tabular}{|l|} 
Learner perception of \\
multimodal \\
synchronous \\
computer-mediated \\
communication in \\
foreign language \\
classrooms
\end{tabular} & $\begin{array}{l}\text { Learner } \\
\text { perception, } \\
\text { technology, and } \\
\text { intercultural } \\
\text { competence }\end{array}$ & $\begin{array}{l}55 \text { participants from } \\
\text { three different } \\
\text { universities were } \\
\text { selected. Questionnaire, } \\
\text { interview, transcripts of } \\
\text { students' discussion } \\
\text { were used to collect } \\
\text { data. }\end{array}$ & $\begin{array}{l}\text { Students' attention during instruction } \\
\text { and cultural issues were identified to } \\
\text { be effective on students' attitudes } \\
\text { towards synchronous computer- } \\
\text { mediated communication. }\end{array}$ \\
\hline 4 & $\begin{array}{c}\text { Hirakawa, } \\
\text { Shibuya, \& } \\
\text { Endo (2019) }\end{array}$ & $\begin{array}{l}\text { Explicit instruction, } \\
\text { input flood or study } \\
\text { abroad: Which helps } \\
\text { japanese leamers of } \\
\text { english acquire } \\
\text { adjective ordering? }\end{array}$ & $\begin{array}{l}\text { Grammar } \\
\text { (learners' } \\
\text { acquisition of } \\
\text { adjective ordering } \\
\text { restrictions) }\end{array}$ & $\begin{array}{l}56 \text { students participated } \\
\text { in this study and } \\
\text { divided into two study } \\
\text { groups and received } \\
\text { different interventions. } \\
\text { Pretest-posttest design } \\
\text { was used to collect and } \\
\text { analyze data. }\end{array}$ & $\begin{array}{l}\text { The only group that outperformed } \\
\text { other groups was explicit instruction } \\
\text { group. The authors "claim that } \\
\text { positive evidence alone does not } \\
\text { guarantee L2 acquisition of AOR" (p. } \\
\text { 158). }\end{array}$ \\
\hline
\end{tabular}


Appendix III

A sample of data from The Modern Language Journal

\begin{tabular}{|c|c|c|c|c|c|}
\hline \multicolumn{6}{|c|}{ The Modern Language Journal } \\
\hline Number & Author(s) & Topic & $\begin{array}{c}\text { Focus of } \\
\text { Article }\end{array}$ & Data Collection Method & Results \\
\hline 1 & $\begin{array}{c}\text { Suzuki, } \\
\text { Nakata, \& } \\
\text { Dekeyser } \\
(2019 \mathrm{a})\end{array}$ & $\begin{array}{l}\text { Optimizing } \\
\text { Second } \\
\text { Language } \\
\text { Practice in the } \\
\text { Classroom: } \\
\text { Perspectives } \\
\text { from Cognitive } \\
\text { Psychology }\end{array}$ & \begin{tabular}{|l|} 
language \\
teaching and \\
strategy
\end{tabular} & \begin{tabular}{l|} 
Participants were divided into \\
four groups. Pretest, immediate \\
posttest, and delayed posttest
\end{tabular} & $\begin{array}{l}\text { "The best test scores were } \\
\text { obtained when the exercises had } \\
\text { served the purpose of retrieval, } \\
\text { although this advantage shrank in } \\
\text { the delayed posttest (where scores } \\
\text { were poor regardless of treatment } \\
\text { condition). On average } 70 \% \text { of the } \\
\text { posttest errors produced by the } \\
\text { learners who had tackled the } \\
\text { exercises by trial-and-error were } \\
\text { duplicates of incorrect responses } \\
\text { they had supplied at the exercise } \\
\text { stage, which indicates that } \\
\text { corrective feedback was often } \\
\text { ineffective" (p. } 551 \text { ) }\end{array}$ \\
\hline 2 & $\begin{array}{c}\text { Subtirelu, } \\
\text { Borowczyk, } \\
\text { Hermandez, } \\
\text { \& Venezia } \\
\text { (2019) }\end{array}$ & $\begin{array}{l}\text { Recognizing } \\
\text { Whose } \\
\text { Bilingualism? } \\
\text { A Critical } \\
\text { Policy Analygis } \\
\text { of the Seal of } \\
\text { Biliteracy }\end{array}$ & Biliteracy & $\mathrm{N} / \mathrm{A}$ & $\begin{array}{l}\text { "This article concludes by } \\
\text { suggesting improvements in policy } \\
\text { and directions for future research } \\
\text { that might contribute to addressing } \\
\text { these inequities" (p. 371). }\end{array}$ \\
\hline
\end{tabular}


Appendix IV

A sample of theme table

\begin{tabular}{|c|c|c|c|c|c|}
\hline \multicolumn{6}{|c|}{ Themes } \\
\hline $\begin{array}{l}\text { Language Teaching } \\
\text { strategies and } \\
\text { Pedagogical } \\
\text { Recommendations for } \\
\text { teachers }\end{array}$ & $\begin{array}{l}\text { Memory and } \\
\text { Language } \\
\text { Development }\end{array}$ & $\begin{array}{l}\text { Social Aspects in } \\
\text { Second Language } \\
\text { Acquisition }\end{array}$ & $\begin{array}{c}\text { Advanced } \\
\text { Influential Factors } \\
\text { in Second } \\
\text { Language } \\
\text { Acquisition }\end{array}$ & $\begin{array}{c}\text { Segmental and } \\
\text { Super-segmental } \\
\text { Features }\end{array}$ & $\begin{array}{l}\text { Language skills, } \\
\text { subskills, and } \\
\text { Language } \\
\text { Development }\end{array}$ \\
\hline $\begin{array}{l}\text { peer interaction and } \\
\text { second language } \\
\text { development }(2012)\end{array}$ & $\begin{array}{l}\text { The role of working } \\
\text { memory in } \\
\text { language } \\
\text { development } \\
(2016)\end{array}$ & $\begin{array}{l}\text { Viewpoint (Social } \\
\text { dimensions of } \\
\text { language } \\
\text { development) } \\
(2019)\end{array}$ & $\begin{array}{l}\text { Motivation, } \\
\text { language choice, } \\
\text { and multilingualism } \\
(2017)\end{array}$ & $\begin{array}{l}\text { Segmental features } \\
\text { (phonology) } \\
(2015)\end{array}$ & $\begin{array}{l}\text { Nativelike } \\
\text { proficiency } \\
(2012)\end{array}$ \\
\hline $\begin{array}{l}\text { Form-focused } \\
\text { instruction } \\
(2019),(2015),(2013)\end{array}$ & $\begin{array}{l}\text { Individual } \\
\text { differences and } \\
\text { cognitive abilities } \\
\text { (reasoning demands } \\
\text { and working } \\
\text { memory) } \\
(2015)\end{array}$ & $\begin{array}{l}\text { "Shame and guilt } \\
\text { from social } \\
\text { psychology into } \\
\text { second language } \\
\text { acquisition (SLA)" } \\
\text { (P. 632) } \\
(2018)\end{array}$ & $\begin{array}{l}\text { "The relationship } \\
\text { among perceptions, } \\
\text { attitudes, and } \\
\text { actually opting to } \\
\text { study a language } \\
\text { (henceforth, } \\
\text { uptake)" (p. } 902 \text { ) } \\
(2014)\end{array}$ & $\begin{array}{l}\text { The effects of } \\
\text { having knowledge } \\
\text { about metaphoric } \\
\text { gestures and its } \\
\text { effects on learning } \\
\text { L2 supersegmental } \\
\text { features } \\
(2019)\end{array}$ & $\begin{array}{l}\text { Biliteracy } \\
(2019)\end{array}$ \\
\hline $\begin{array}{l}\text { Language teaching } \\
\text { (explicit instruction } \\
\text { and background } \\
\text { knowledge } \\
(2018)\end{array}$ & $\begin{array}{l}\text { Cognitive } \\
\text { complexity and } \\
\text { feedback } \\
(2013)\end{array}$ & $\begin{array}{l}\text { Sociocognitive } \\
\text { theory and } \\
\text { language } \\
\text { development } \\
(2018)\end{array}$ & $\begin{array}{l}\text { Motivation and L2 } \\
\text { development } \\
(2014)\end{array}$ & $\begin{array}{l}\text { "Supersegmental } \\
\text { features of lexical } \\
\text { stress" (p. 319) } \\
(2017)\end{array}$ & $\begin{array}{l}\text { The connection } \\
\text { between L2 writing } \\
\text { process, its } \\
\text { reflection on } \\
\text { language and } \\
\text { language } \\
\text { development }\end{array}$ \\
\hline $\begin{array}{l}\text { Teacher's assessment } \\
\text { literacy and language } \\
\text { instruction } \\
(2018)\end{array}$ & $\begin{array}{l}\text { Second language } \\
\text { acquisition process } \\
\text { in monolinguals } \\
\text { and bilinguals } \\
\text { (2011) }\end{array}$ & $\begin{array}{l}\text { Culture and } \\
\text { language } \\
\text { development } \\
(2018)\end{array}$ & $\begin{array}{l}\text { Aptitude in leaming } \\
\text { a second language } \\
(2013)\end{array}$ & $\begin{array}{l}\text { Intonation } \\
(2010),(2014)\end{array}$ & $\begin{array}{l}\text { Background } \\
\text { knowledge and } \\
\text { writing } \\
(2019)\end{array}$ \\
\hline
\end{tabular}

